\title{
Tritium as tracer of groundwater pollution extension: case study of Andralanitra landfill site, Antananarivo-Madagascar
}

\author{
Voahirana Ramaroson $^{1,2} \cdot$ Christian Ulrich Rakotomalala ${ }^{1} \cdot$ Joel Rajaobelison $^{1,2} \cdot$ Lahimamy Paul Fareze $^{1}$. \\ Falintsoa A. Razafitsalama ${ }^{1} \cdot$ Mamiseheno Rasolofonirina ${ }^{2}$
}

Received: 17 November 2017 / Accepted: 26 March 2018 / Published online: 11 April 2018

(c) The Author(s) 2018

\begin{abstract}
This study aims to understand the extension of groundwater pollution downstream of a landfill, Andralanitra-Antananarivo-Madagascar. Twenty-one samples, composed of dug well waters, spring waters, river, and lake, were measured in stable isotopes $\left(\delta^{2} \mathrm{H}, \delta^{18} \mathrm{O}\right)$ and tritium. Results showed that only two dug well waters, collected at the immediate vicinity of the landfill, have high tritium activities (22.82 TU and 10.43 TU), probably of artificial origin. Both upstream and further downstream of the landfill, tritium activities represent natural source, with values varying from $0.17 \mathrm{TU}$ to $1.46 \mathrm{TU}$ upstream and from 0.88 TU to 1.88 TU further downstream. Stable isotope data suggest that recharge occurs through infiltration of slightly evaporated rainfall. Using the radioactive decay equation, the calculated tracer ages related to two recent ground water samples collected down gradient of the landfill lay between [8-15] years and [4-7] years, taking into account the uncertainty of tritium measurements. For the calculation, a value of $2.36 \mathrm{TU}$ was taken as $A_{\mathrm{o}}$. The latter was estimated based on similarity between stable isotope compositions of nearby spring and dug well waters as well as tritium activities of the local precipitation. Calculation of the tritium activities from the contaminated water point having 22.82 TU to further downstream using the calculated tracer ages showed values of one order of magnitude higher than the measured values. The absence of hydrological connection from the contaminated water point to further downstream the landfill would explain the lower tritium activities measured. Groundwater pollution seems to be limited to the closest proximity of the landfill.
\end{abstract}

Keywords Groundwater pollution · Landfill $\cdot$ Contamination · Close proximity $\cdot$ Tritium $\cdot$ Andralanitra

\section{Introduction}

Landfill use as municipal solid waste management has negative impact on water resources. Mostly, water quality has been deteriorated in different parts worldwide. In an urban Community of Casablanca-Morocco, the pollution plume moved further through an area of agricultural vocation within a decade as landfill leachate infiltrated through the fractured quartzite formation (Fekri et al. 2012). Aljaradin

Voahirana Ramaroson

vramaroson@yahoo.com

1 National Institute for Nuclear Science and Technology (INSTN-Madagascar), P.O. Box 3907, 101 Antananarivo, Madagascar

2 Domain of Science and Technology, Mention in Physics, Nuclear and Applied Physics Laboratory, University of Antananarivo, P.O. Box 906, 101 Antananarivo, Madagascar and Persson (2012) investigated the environmental impact of municipal solid waste landfills in semi-arid climates, in a case study for Jordan. Results showed a gradual increase of chemical elements concentrations in groundwater wells nearer the landfill site. Besides, municipal landfill leachates also have high tritium activities as reported by several authors (Mutch and Mahony 2008; Hicks et al. 2000; Castañeda et al. 2012).

Tritium is the radioactive isotope of hydrogen. It has different attributes that make it distinctive among environmental tracers of groundwater pollution: it does not interact with the aquifer materials during movement through the porous media and is considered conservative geochemically (Holland and Karl 2010); its activity in water sample can be measured at low level (IAEA et al. 2001) through electrolytic enrichment prior to quantification. As tritium analysis especially can identify contamination at less than $1 \%$, the use of tritium and other isotopes can substitute large number of chemical parameters, especially in a first phase of 
site characterization (Raco et al. 2013). Therefore, scientists commonly use tritium to study the extent of groundwater pollution. Tritium allowed detecting pollution migration to groundwater even at greater distance from a landfill site in Italy (Tazioli 2011). Tritium source measurements enabled to identify accurately leachate flow in a landfill zone in Ireland (Murphy et al. 2016).

The landfill site of Andralanitra is located at about $10 \mathrm{~km}$ from the capital city Antananarivo and has been used for household waste disposal for 50 years (Rasoanaivo 2016). Originally planned to receive waste within an area of 130,000 square meters, the site is currently overloaded due to the increasing population over the years and occupies 50,000 square meters more than the authorized area. With a total weight of waste between 450 and 600 tons daily, the site height reached 10-15 m in 2010 (French Development Agency 2010). Besides, the site does not have any confinement or sealing system (Le Sourd 1999), increasing the risk of contamination as leachate seeps downward through the underlying geological formation. As a result, the shallow aquifer is easily vulnerable to pollution.

In 2010, the French Development Agency (FDA) studied the water quality in some dug wells surrounding the waste deposit site and stated the presence of chemical pollutant, in particular in one sample collected just down gradient of the landfill (FDA 2010). The National Institute for Nuclear Science and Technology-Madagascar (INSTN-Madagascar) measured major and minor ions as well as heavy metals in dug well waters, river, and lake and the results confirmed the previous findings by FDA (Andrianiana 2013; Rakotomalala 2014).

The present study uses environmental isotopes $\left({ }^{2} \mathrm{H},{ }^{18} \mathrm{O}\right)$ and in particular tritium $\left({ }^{3} \mathrm{H}\right)$ to assess the extent of the pollution in the shallow aquifer within $700 \mathrm{~m}$ downstream the landfill.

\section{Site description}

\section{Geographical location}

The study area is located in the Central Highlands Plateau, District of Northern Antananarivo in the region of Analamanga, at about $10 \mathrm{~km}$ of downtown Antananarivo. Paddy rice fields directly surround the landfill, except in the Northwestern part, where small agglomeration of households limits the site. The Ampasimbe River flows downstream of the landfill site. It also limits the study area on the Southeastern side (Fig. 1).

\section{Geographical relief}

More or less rugged hilly area characterizes the terrain. It is slightly inclined on which blocks of hard rocks such as granites lie (Raunet 1980). Surrounding the plain of Andralanitra, the altitude varies from 1280 to $1300 \mathrm{~m}$ (Douessin 1976).

\section{Climate}

Located between downtown Antananarivo and its Northern District, the study area features a subtropical highland climate, which is of Antananarivo. It has two distinct seasons: the hot and rainy seasons, from October to April, and the cold and dry seasons, from May to September. The driest period is from June to August.

The hot season has an average maximum temperature of $26.3{ }^{\circ} \mathrm{C}$, while the cold season has an average minimum temperature of $11.1{ }^{\circ} \mathrm{C}$ (Climate data from 1981 to 2017, Pogodaiklimat 2016). Antananarivo receives on average $1437 \mathrm{~mm}$ of precipitation annually (Pogodaiklimat 2016).

\section{Geological settings}

Archaean and Neoproterozoic igneous and metamorphic rocks of the Basement Complex underlay the Central Highlands Plateau. The Neoproterozoic Granites are deeply weathered (Davies, 2008). Alluvial plain embedded in thick saprolite cover, which lies on metamorphic Precambrian basement rocks characterizes Antananarivo (Rasolomanana et al. 2011). The alluvial plain resulted from the filling up of one slanting compartment of the crystalline Basement. From top to bottom, successive alluvium types occur, schematically:

- an outcrop of thin clayey silt, which is the substratum of paddy rice fields;

- of 0.5-3 m thick;

- pure peat layer of up to $1.5 \mathrm{~m}$ thick;

- sandy kaolin white clays, of $2 \mathrm{~m}$ thick;

- sand of 10-15 m thick, with increasing grain size towards the bottom (Rakoto et al. 2017).

Extract of the geological map of Antananarivo (Fig. 2a) indicates that the study area occurs on the alluvial plain, of which an illustration of the stratigraphic log is shown in Fig. 2b. 


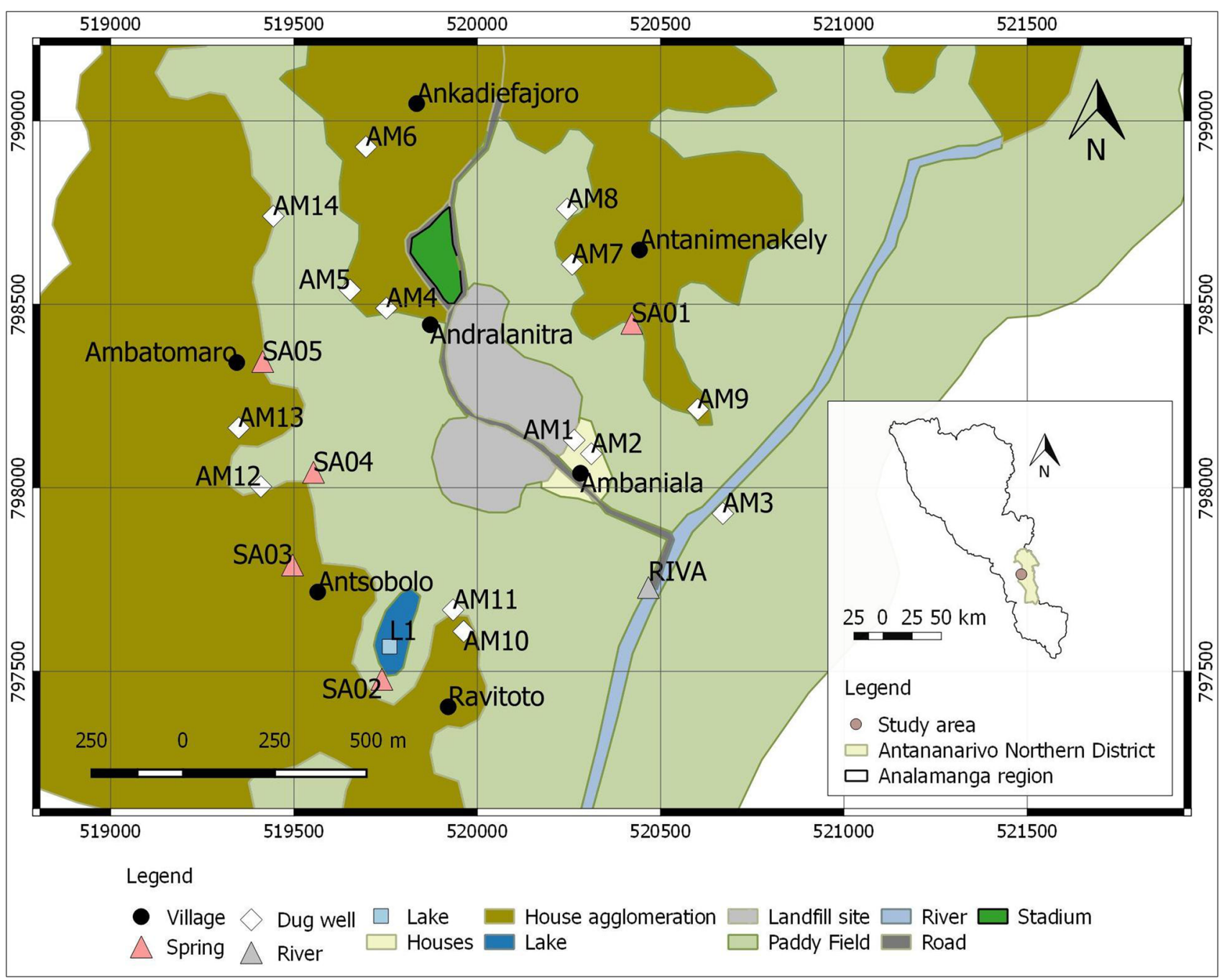

Fig. 1 Study area location, Source Google Earth, georeferenced and digitized using QGIS 2.14 Essen

\section{Hydrogeological settings}

The main aquifer reservoir of the alluvial plain consists of thick layer (more than $10 \mathrm{~m}$ ) of alluvial sand, which covers the whole plain area and plays the role of drainage, considering its permeability. Moreover, a lateritic-kaolinic formation, occurring on the interfluve constitutes an unconfined aquifer and can be readily exploited through individual traditional dug wells (Rasolomanana et al. 2011).

Overlaying the unaltered basement is arena of mica enriched sandy clay materials, kaolinic feldspar and ferromagnesian minerals covered by clay layer and constitutes a confined aquifer (Dussarrat and Ralaimarp 1993).

In the metamorphic basement, groundwater flows through fractures network. In some area, where the metamorphic rocks constitute the base level of the outcropping geological formations, the aquifer is discontinued and recharge occurs through the overlaying arena. In these areas, the residual term, which did not undergo the evapotranspiration process, joins the underlaying aquifer, which is also recharged by the surficial hydrographic network (Rakoto et al. 2017).

The groundwater recharge mechanism in the alluvial plain is of three complementary processes: vertical rainfall infiltration, lateral infiltration through the fractures network and the altered rocks, and vertical drainage of the surficial hydrographic network (Dussarrat and Ralaimarp 1993; Dussarrat 1992; Grillot and Ferry 1990).

The occurrence of several emerging springs in the alluvial plain allows the flooding of paddy rice fields, even during the low flow period (Rasolomanana et al. 2011).

The hydroisohypses map of the study area (Fig. 3) is obtained from water table elevation of the sampling points. Groundwater discharge occurs into springs in different parts of the study area, both upstream and downstream of the landfill as well as on each side of it. Pertaining to the study area 


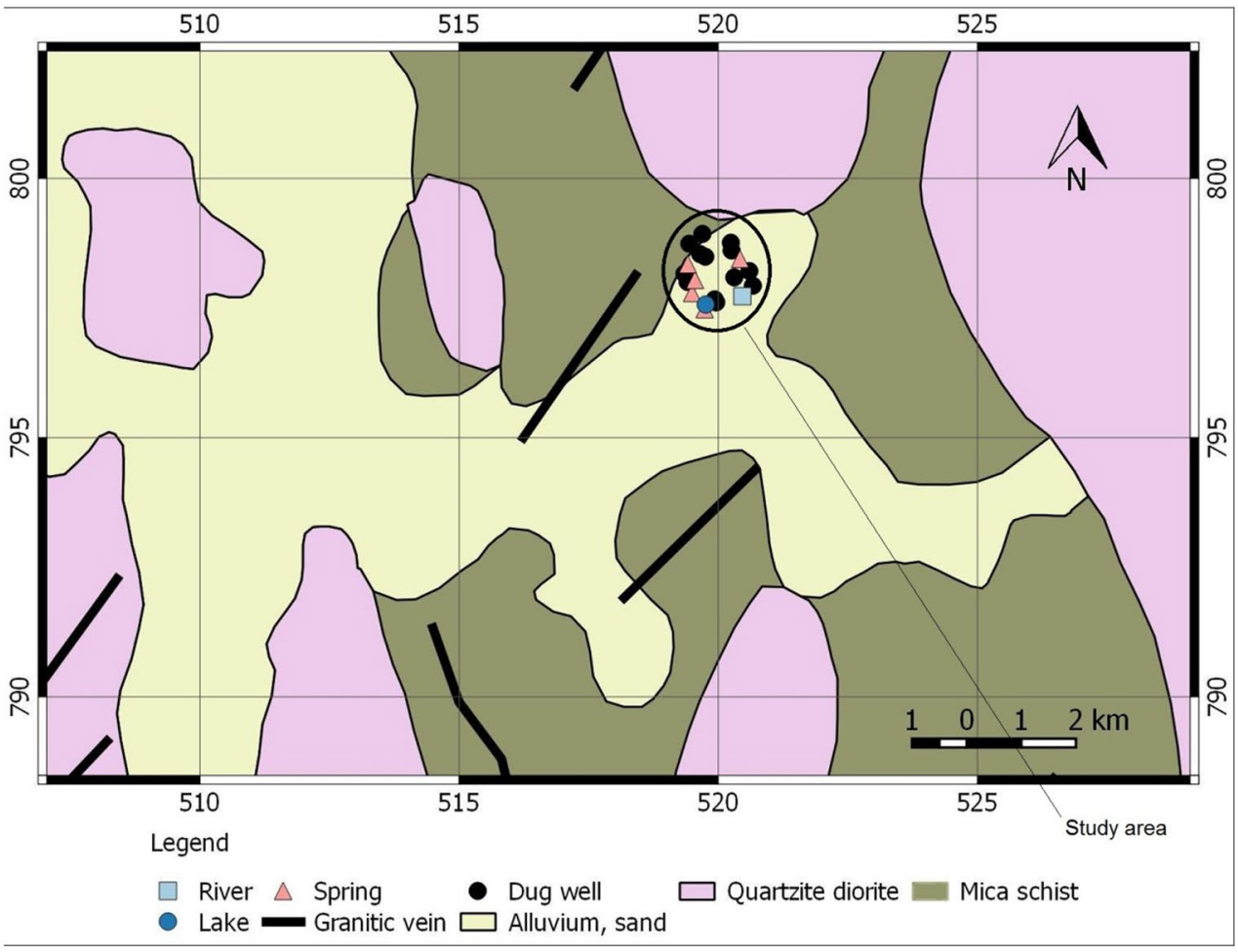

a

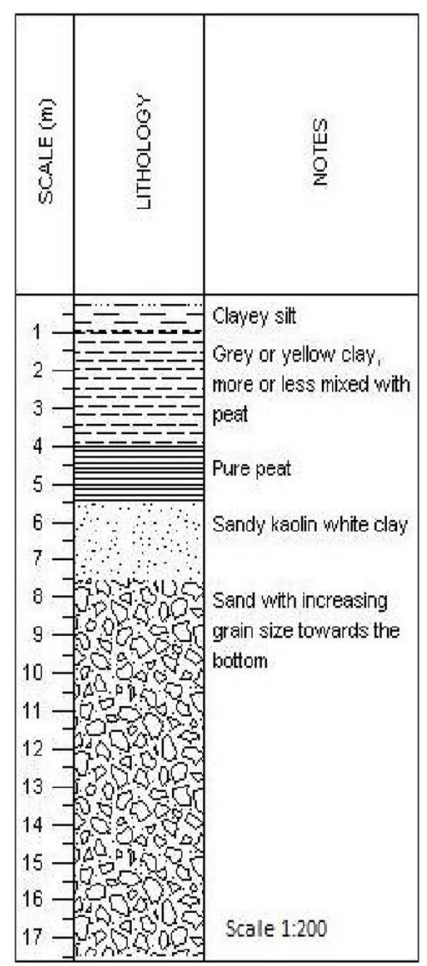

b

Fig. 2 a Extract of the geological map of Antananarivo Source GEOL500 database. b Stratigraphic log of the alluvial plain (Rakoto et al. 2017)

solely, discontinuous groundwater flow occurs. Different hydroisohypse patterns are found in the eastern and western parts of the landfill. In the eastern part, groundwater velocity is higher than in the western part. Higher water tables in the eastern part would explain the higher velocity as groundwater flows in sand of increasing grain size deeper into the aquifer (stratigraphic log of the alluvial plain in Fig. 2b).

\section{Methodology}

\section{Field and laboratory works}

The sampling campaign was carried out in October 2011, within $700 \mathrm{~m}$ upstream and downstream of the landfill site (Fig. 1). Traditional dug well, spring, river, and lake composed the 21 sampling points visited, which are distributed around the landfill, as illustrated in Fig. 1. Notably, two dug wells occurred at the immediate vicinity of the waste deposit site. All the dug well-sampling points were relatively shallow with a maximum depth of $6 \mathrm{~m}$ and a minimum of $2 \mathrm{~m}$, resulting in high water tables for the shallowest ones. Water tables were found from 0.95 to $5 \mathrm{~m}$ below the soil surface. All samples collected occur in the alluvium formation.

All samples were collected in plastic polyethylene bottles: 50 -mL bottle for water-stable isotope $\left({ }^{2} \mathrm{H},{ }^{18} \mathrm{O}\right)$ analysis and
1000-mL bottle for tritium analysis. The Water and Climate Unit of the National Center for Energy and Nuclear Science and Technology (CNESTEN)-Morocco performed the isotope analyses. Prior to quantification by low-level Liquid Scintillation Counter TRICARB 3170 TR/SL, samples were distilled and underwent electrolytic enrichment for tritium measurements. Water-stable isotopes were measured by mass spectrometer IRMS Delta Plus by $\mathrm{CO}_{2}$ and $\mathrm{H}_{2}-\mathrm{H}_{2} \mathrm{O}$ equilibration.

\section{Tritium}

Tritium occurs naturally as reaction product between atmospheric nitrogen and thermal neutrons as per Eq. (1):

${ }^{14} \mathrm{~N}+n \rightarrow{ }^{12} \mathrm{C}+{ }^{3} \mathrm{H}$.

It is a short-lived radioisotope, with half life of 12.43 years (Mann et al. 1982; Varlam et al. 2005), used for young groundwater dating. The "effective age" is determined using the radioactive decay equation as per Eq. (2), where $A$ is the groundwater tritium activity measured at sampling time $t, A_{\mathrm{o}}$ is the tritium activity at the time of recharge, and $\lambda$ is the radioactive decay constant:

$A=A_{\mathrm{o}} \mathrm{e}^{-\lambda t}$.

As the age calculated from tritium is not the real age, but an average age since water builds up in the aquifer for years 
Fig. 3 Hydroisohypses map of the study area

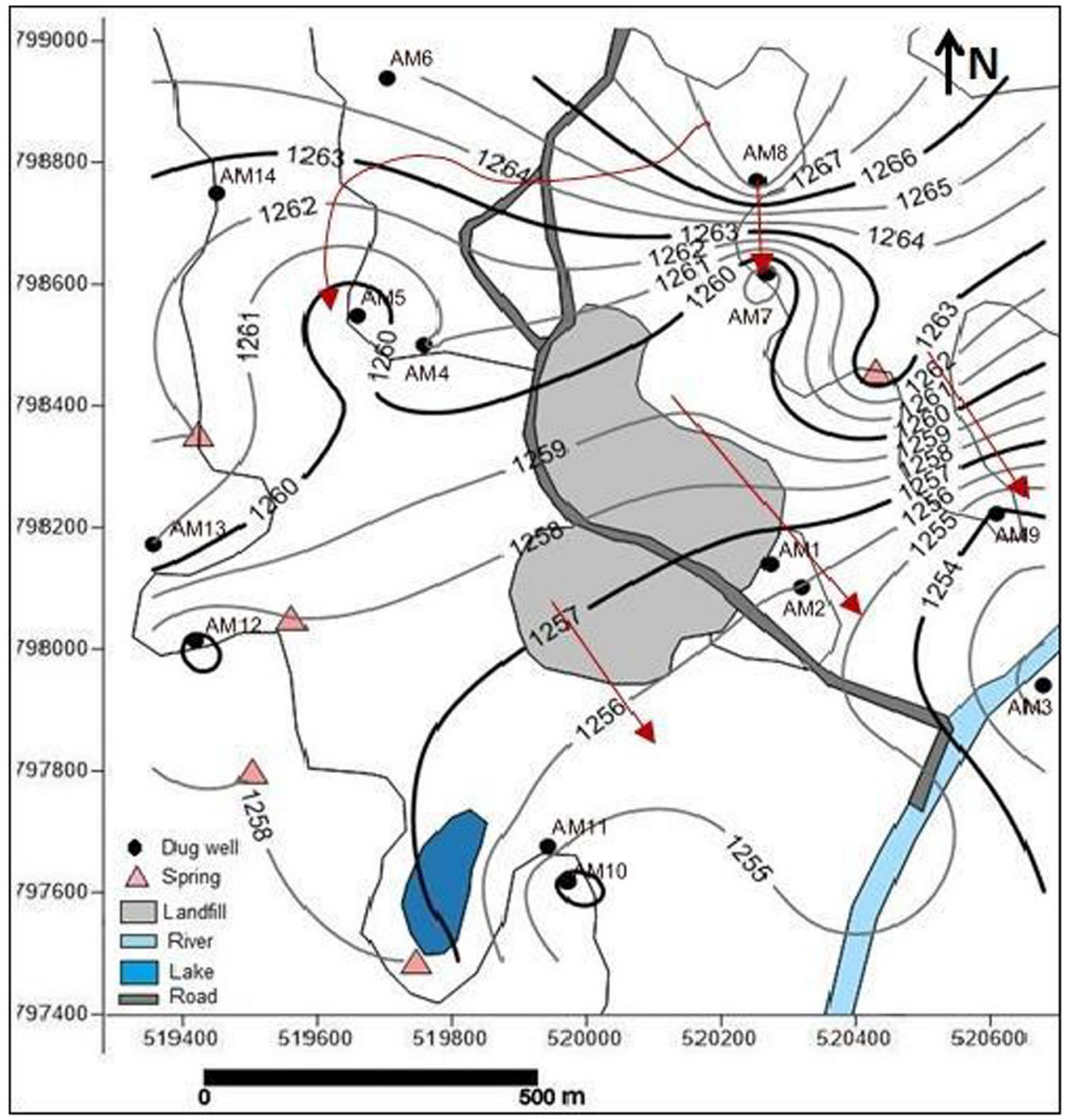

as a result of several annual recharges, the term "effective age" is used (Mazor 2004). Considering that fact the age calculated is not the groundwater age but rather the "tracer age".

Equation (2) is used to determine the "tracer age" or "effective age" related to young groundwater as classified from semi-quantitative evaluation of the tritium content in the water sample, assuming that there is no mixing with any type of aquifer materials.

\section{Results and discussion}

Tables 1 and 2 show the isotope data for dug well waters and for spring, river, and lake waters, respectively.

Tritium data are given with uncertainties, while waterstable isotope results were measured with $\pm 0.15 \%$ o for $\delta^{18} \mathrm{O}$ and $\pm 2 \%$ or $\delta^{2} \mathrm{H}$ (Analysis report no. 001/12-under reference UEC-12-001 of March 1, 2012-CNESTEN).

Well waters are categorized in three groups:
Table 1 Isotope data of dug well waters

\begin{tabular}{cccc}
\hline Sample code & ${ }^{3} \mathrm{H}(\mathrm{TU})$ & $\begin{array}{l}\delta^{18} \mathrm{O}(\% \circ \\
\text { VSMOW })\end{array}$ & $\delta^{2} \mathrm{H}(\%$ VSMOW $)$ \\
\hline Group 1 & & & \\
AM1 & $22.82 \pm 0.67$ & -6.81 & -42.80 \\
AM2 & $10.43 \pm 0.40$ & -6.63 & -40.77 \\
Group 2 & & & \\
AM3 & $0.84 \pm 0.21$ & -7.30 & -46.01 \\
AM9 & $0.88 \pm 0.24$ & -7.51 & -46.63 \\
AM10 & $1.28 \pm 0.24$ & -5.91 & -39.12 \\
AM11 & $1.88 \pm 0.24$ & -6.22 & -39.90 \\
Group 3 & & & \\
AM4 & $0.17 \pm 0.19$ & -7.17 & -45.37 \\
AM5 & $1.15 \pm 0.23$ & -7.00 & -44.55 \\
AM6 & $1.46 \pm 0.27$ & -6.80 & -42.86 \\
AM7 & $1.02 \pm 0.28$ & -7.14 & -44.98 \\
AM8 & $1.05 \pm 0.26$ & -7.17 & -44.55 \\
AM12 & $1.39 \pm 0.24$ & -7.46 & -48.64 \\
AM13 & $1.18 \pm 0.20$ & -7.64 & -50.03 \\
AM14 & $1.06 \pm 0.20$ & -6.28 & -39.98 \\
\hline
\end{tabular}


Table 2 Isotope data of spring, river, and lake waters

\begin{tabular}{llll}
\hline Spring waters & ${ }^{3} \mathrm{H}(\mathrm{TU})$ & $\begin{array}{l}\delta^{18} \mathrm{O}(\% \circ \\
\text { VSMOW })\end{array}$ & $\delta^{2} \mathrm{H}(\% \circ$ VSMOW $)$ \\
\hline $\mathrm{SA01}$ & $2.36 \pm 0.31$ & -7.51 & -48.63 \\
$\mathrm{SA02}$ & $1.58 \pm 0.08$ & -6.43 & -41.89 \\
$\mathrm{SA03}$ & $1.89 \pm 0.08$ & -7.25 & -48.04 \\
$\mathrm{SA04}$ & $1.68 \pm 0.08$ & -7.69 & -51.67 \\
$\mathrm{SA05}$ & $2.30 \pm 0.12$ & -7.50 & -51.33 \\
River water & & & \\
$\quad$ RIVA & 3.23 & -2.78 & -25.81 \\
Lake water & & & \\
$\quad$ L1 & 2.54 & 2.26 & 3.97 \\
\hline
\end{tabular}

- Group 1 composed of AM1 and AM2, sampled from the two dug wells located just down gradient of the landfill site and which have high tritium activities (Table 1)

- Group 2 composed of AM3, AM9, AM10, and AM11, sampled from the four dug wells located downstream the landfill, within $700 \mathrm{~m}$ from AM1

- Group 3 composed of AM4, AM5, AM6, AM7, AM8, AM12, and AM13, sampled upstream of the landfill, except AM12, which was collected rather at the waste deposit level than up gradient of it.

\section{Theoretical aspect}

\section{Stable isotopes}

Group 1 samples have similar stable isotope content, indicating connection and continuous flow from AM1 to AM2.

In Group 2, where samples were collected downstream of the landfill, the samples are paired according to their geographical locations: the pair (AM10, AM11), sampled in the western part of the landfill, has similar stable isotope content, highlighting hydrological connection between the sampling points. The same is also true for the other pair (AM3, AM9), which was collected in eastern part of the landfill. However, (AM10, AM11) and (AM3, AM9) have different stable isotope compositions, indicating that the absence of hydrological connection and probably different groundwater recharge mechanisms. (AM10, AM11) is more enriched in heavy isotopes than (AM3, AM9), suggesting either closer recharge area for (AM10, AM11) or the occurrence of slight rainfall evaporation prior to infiltration. With a water table of $1.5 \mathrm{~m}, \mathrm{AM} 11$ is highly subject to evaporation. The stable isotope composition difference is in agreement with the hydroisohypses map, which shows different groundwater flow patterns in the eastern and western parts of the landfill.

Comparing Group 1 and Group 2, stable isotope data also lead to the assumption of groundwater flow discontinuity from the highly tritium contaminated groundwater to further

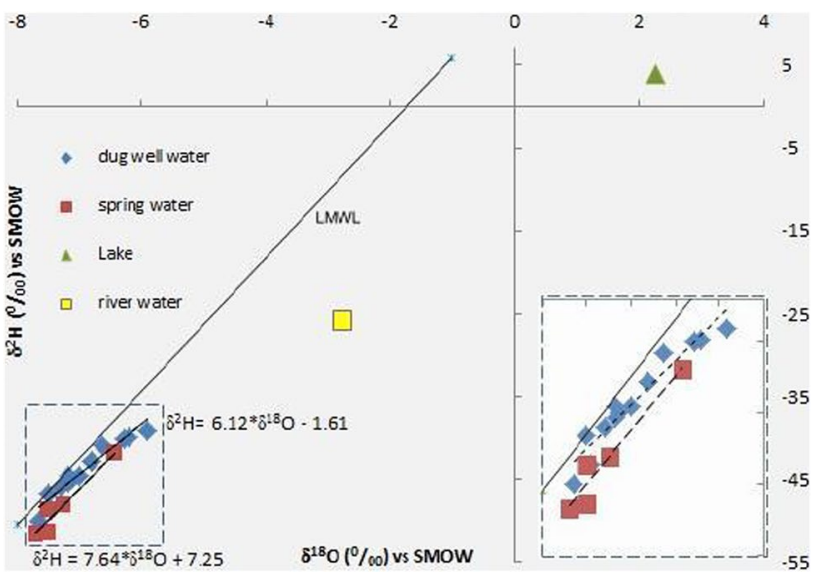

Fig. 4 Stable isotope composition of the different water types collected in the study area

downstream in the water points. Such a discontinuity would hinder contamination to spread over into the aquifer.

Group 3 can be classified as follows:

- the subgroup composed of AM4, AM5, AM8, and AM7;

- the pair (AM12, AM13);

- AM6, which is sampled at the extreme north of the study area, upstream of the landfill site. AM6 is slightly more enriched in heavy isotopes than (AM4, AM5, AM8, and AM7), but has very similar stable isotope content than AM1. This suggests a continuous groundwater flow from upstream of the landfill site to AM1.

- AM14, which is sampled close to AM6, but is much more enriched in heavy isotopes than the latter sample.

Besides, AM14 is isotopically identical to AM11, which was sampled downstream of the landfill. This leads to the assumption of probable connection from upstream to downstream of the waste deposit site on its western side. This is, however, not in agreement with the groundwater flow pattern. Moreover, the different stable isotope contents of the water samples collected between AM14 and AM11 would rather indicate groundwater flow discontinuity, which could be explained by the presence of several emerging springs. Examining the tritium data further in the discussion helps highlight the groundwater flow and the spread of the contamination into the aquifer system.

The stable isotope composition of the dug well waters (Fig. 4) plots below the local meteoric water line of equation $\delta^{2} \mathrm{H}=8.05 \times \delta^{18} \mathrm{O}+10$ (IAEA 2007; Fareze et al. 2016) and indicates the occurrence of evaporation prior to rainfall infiltration, with regression line of $\delta^{2} \mathrm{H}=6.12 \times \delta^{18} \mathrm{O}-1.61\left(R^{2}=0.924\right)$. Spring waters are more depleted in stable isotope contents (table 2) and plot below the LMWL with regression line of 
$\delta^{2} \mathrm{H}=7.64 \times \delta^{18} \mathrm{O}+7.25\left(R^{2}=0.937\right)$. This suggests that the isotope composition of spring waters results from a mixture of condensed rainfall and infiltrated evaporated rainfall down to the aquifer (the latter would be probably of minor proportion), which would emerge as springs.

The lake and the river waters are both enriched in stable isotopes and plot far below the LMWL.

\section{Tritium}

Group 1 is noticeably distinguishable from Group 2 and Group 3 because of its abnormally high tritium activities. The values of 22.82 and 10.43 TU indicate contamination through percolation of the landfill leachate (Nigro et al. 2017), which would originate from artificial tritium sources. Although the exact source of tritium is unknown in the study area, high level tritium containing items such as gaseous tritium lighting devices, exit signs, watches, or clocks (Murphy et al. 2016), or key chains are very probable to end up with municipal solid waste, in particular when no waste selection policies exist as for the Andralanitra site.

For Group 2, the tritium activities reflect a natural origin and the values greater than $1 \mathrm{TU}$ (AM10 and AM11) indicate recently recharged groundwater (Farid et al. 2015). For AM3 and AM9, having, respectively, 0.84 and $0.88 \mathrm{TU}$, there would be mixture of old and young groundwater, or slower groundwater velocity through more impervious layer at depth (AM3 and AM9 have the lowest water tables, of 4 and $5.7 \mathrm{~m}$, respectively). The stratigraphic $\log$ (Fig 2b) would support the latter assumption, since at $4 \mathrm{~m}$ to $6 \mathrm{~m}$ depth, groundwater occurs in pure peat layer of $2 \mathrm{~m}$ thickness. From his study on the permeability of various grades of sand and peat and mixture of these with soil and vermiculite, Garman 1952 found that compacted peat in layer of $0.15 \mathrm{~m}$ in depth is almost impervious.

From Group 1 to Group 2, tritium activities drop then considerably with obviously different tritium sources: artificial source just downstream of the landfill and natural source further away from the landfill, with tritium activities less than $1 \mathrm{TU}$ for some ground waters.

For Group 3, the tritium activities also indicate natural sources and young ground waters, except AM4. The latter water sample was collected just upstream of the landfill and has a tritium activity of 0.17 TU. Such a low value refers to old groundwater and indicates groundwater of different source. This infers the absence of continuous flow from upstream to downstream of the landfill. The higher tritium activities in water samples collected downstream of the landfill compared to that collected upstream (NW-SW direction) likely confirm the previous assumption.

\section{Numerical aspect}

The theoretical discussion showed different sources of tritium just downstream of the landfill site and further down from, that is from Group 1 to Group 2. While plotting the variation of tritium activities with distance down gradient of the landfill, from Group 1 to Group 2, and considering AM1 as the contamination point source (Fig 5), the same trends of exponential decrease (with R-squared values approximately equal to 1 ) of the tritium activities are observed in two different directions down gradient the landfill, as shown in Fig 5:

- From AM1 to AM9 and AM3 (AM9 and AM3 show mixture of young and old groundwater tritium values), the equation is $y=21.053 \mathrm{e}^{-0.004 x}$, with $R^{2}$ of 0.983 .

- From AM1 to AM10 and AM11 (AM10 and AM11 have young groundwater tritium values), the equation is $y=24.581 \mathrm{e}^{-0.006 x}$, with $R^{2}$ of 0.939 .

The trend line equation can be generalized as $A=A_{\mathrm{o}} \mathrm{e}^{-k_{1} \cdot x}(1)$, where $A_{\mathrm{o}}$ is the tritium activity of AM1 (at $15 \mathrm{~m}$ from the landfill site), and $A$ is the tritium activity at distance $x(\mathrm{~m})$ from AM1.

While assuming that an exponential decay governed by the radioactive decay, Eq. (2) is taking place along the groundwater flow path, in different directions from the source of contamination, the tracer age in AM10, and AM11 can be calculated. For AM3 and AM9, such calculation leads to erroneous results, since their tritium values indicate mixture of old and young groundwater.

From Eq. (2), the "tracer age" related to the young ground waters can be calculated with an estimation of $A_{\mathrm{o}}$.

Estimation of $A_{\mathrm{o}}$

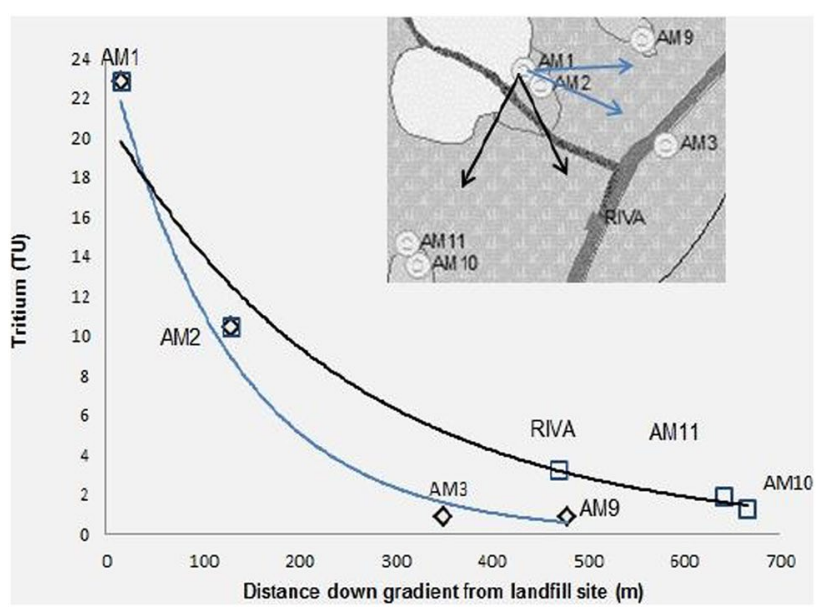

Fig. 5 Tritium activities variation with distance down gradient the landfill site 
- The tritium activity of Ampasimbe River sample (RIVA, of $3.2 \mathrm{TU}$ ) lays in the range of the local precipitation tritium activities and could be taken as $A_{0}$, in case the River is not a discharge point. Considering the tritium activities of the dug well waters from the contamination point AM1 to RIVA, the latter sample has the highest activity, implying that the River is likely not a discharge point, since tritium activity decays along the groundwater flow path.

- However, from the stable isotope composition graph (Fig 4), RIVA plots far below the LMWL, indicating the occurrence of strong evaporation, common for surface waters. This would discard the use of RIVA tritium activity as $A_{\mathrm{o}}$, since the dug well waters are likely to be recharged by infiltration of much less evaporated rainfall, as the stable isotope composition seems to indicate.

- Tritium activities of precipitation in Antananarivo are measured locally and a value of $2.30 \mathrm{TU}$ was measured for October 2011, corresponding to the sampling period. From the Global Network of Isotopes in Precipitation (GNIP) database, the tritium activity of precipitation for the same period in Marion Island (Indian Ocean, South Africa) is $2.40 \mathrm{TU}$ (IAEA/WMO 2017). Those values are very similar to the tritium activities of spring waters SA01 and SA05 (2.36 and 2.30 TU, respectively). This agrees with the stable isotopes contents of SA01 and SA05, which are also similar

- The highest tritium activity of natural origin measured in dug well waters is $1.88 \mathrm{TU}$, inferring an $A_{\mathrm{o}}$ value higher than $1.88 \mathrm{TU}$ due to radioactive decay.

- Spring water SA01 and dug well water AM09, which were collected downstream of SA01, have similar stable isotope composition, implying connection between the two water points and comply with the assumption that the dug well water is a mixture of infiltrated condensed rainfall and small proportion of slightly evaporated one.
From the above considerations, using the tritium activity of SA01 for $A_{\mathrm{o}}$ would be the best estimate for effective age calculation of the young ground waters downstream of the landfill site.

Using Eq. (2), with $A_{\mathrm{o}}=2.36 \mathrm{TU}$, the tracer ages for AM10 and AM11 are calculated and results are given in Table 3, taken into account the limit of the tritium measurements in the water samples. With a practical limit of $0.2 \mathrm{TU}$, the tritium method of "effective hydrological age" is valid within a range of few decades (Mazor 2004).

From these values, tritium activities of AM10 and AM1 1 at the time of sampling can be calculated back using Eq. (2), assuming that continuous groundwater flow path occurs from AM1 to AM10 and AM11.

AM1, with anthropogenic tritium source of $22.82 \mathrm{TU}$, is considered as the starting point.

Table 4 shows substantial difference between calculated and measured tritium activities for AM10 and AM11. Higher tritium activities would have been calculated in AM10 and AM11, since the value of $22.82 \mathrm{TU}$ at the time of sampling has already undergone radioactive decay confirming the difference between calculated and measured values. The abrupt decrease of the tritium concentration over a distance of $700 \mathrm{~m}$ would indicate discontinuity rather than connectivity between the water points, as also indicates the hydroisohypses map. This would prevent the spread of contamination over into the aquifer system. Pollution would be limited to groundwater occurring directly downstream of the landfill site. The occurrence of several emerging springs would obstruct the groundwater flow. Besides, there is similarity between the stable isotope compositions of well and spring waters, inferring a same origin and thus confirming the assumption of discontinuity.
Table 3 Tracer age calculation for young ground waters collected downstream of landfill

\begin{tabular}{llllllc}
\hline Dug well & $A_{\mathrm{o}}(\mathrm{TU})$ & $A(\mathrm{TU})$ & Uncertainty (TU) & $\begin{array}{l}\text { Tracer age } \\
\text { (years) }\end{array}$ & $\begin{array}{l}\text { Lower tracer age } \\
\text { limit (years) }\end{array}$ & $\begin{array}{l}\text { Upper tracer } \\
\text { age limit } \\
\text { (years) }\end{array}$ \\
\hline AM10 & 2.36 & 1.28 & \pm 0.24 & 11 & 8 & 15 \\
AM11 & 2.36 & 1.88 & \pm 0.24 & 4 & 2 & 7 \\
\hline
\end{tabular}

\begin{tabular}{llllll}
\hline Dug well & $\begin{array}{l}\text { Activity of AM1 } \\
\text { as } A_{\mathrm{o}} \text { (TU) }\end{array}$ & Tracer age (years) & $\begin{array}{l}\text { Remaining } \\
\text { activities (TU) }\end{array}$ & $\begin{array}{l}\text { Lower activities } \\
\text { limit (TU) }\end{array}$ & $\begin{array}{l}\text { Upper activi- } \\
\text { ties limit } \\
\text { (TU) }\end{array}$ \\
\hline AM10 & 22.82 & {$[8-15]$} & 12.38 & 10.06 & 14.70 \\
AM11 & 22.82 & {$[4-7]$} & 18.18 & 15.86 & 20.50 \\
\hline
\end{tabular}

Table 4 Calculated tritium activities of young ground waters collected downstream of landfill
مدينة الملك عبدالعزيز

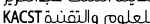




\section{Conclusion}

Tritium data showed that only just down gradient of the waste deposit site that contamination occurs, where much higher tritium activities than of natural origin value were measured in groundwater samples. This is in agreement with chemical results from the previous measurements performed in the landfill site area (FDA 2010; Andrianiana 2013; Rakotomalala 2014). By calculating the "tracer ages" of recent groundwater using the radioactive decay equation (estimation of $A_{\mathrm{o}}$ is based on both the tritium activity and stable isotope composition of spring water sampled close to dug well waters as well as the tritium activity of local precipitation), it was possible to infer from comparison of calculated and measured tritium activities of dug well waters down gradient the landfill site that a discontinuity from the contamination point to the furthest sampling site at about $700 \mathrm{~m}$ probably explains the tritium activities measured.
Acknowledgements The authors are grateful to the International Atomic Energy Agency for its technical and financial support that allowed the isotope analyses, through the Water and Climate Unit of the Centre National de l'Energie, des Sciences et Techniques Nucléaires (CNESTEN)-Morocco, to which we express our appreciation. We also thank the population of Andralanitra and Ambohimangakely for their nice welcome during the field visits.

Open Access This article is distributed under the terms of the Creative Commons Attribution 4.0 International License (http://creativeco mmons.org/licenses/by/4.0/), which permits unrestricted use, distribution, and reproduction in any medium, provided you give appropriate credit to the original author(s) and the source, provide a link to the Creative Commons license, and indicate if changes were made.

\section{Appendix}

See Table 5.
Table 5 Chemical results of water samples collected in the study area

\begin{tabular}{lcccllllr}
\hline Sample code & $\mathrm{Ca}$ & $\mathrm{Mg}$ & $\mathrm{Na}$ & $\mathrm{K}$ & $\mathrm{HCO}_{3-}$ & $\mathrm{Cl}-$ & $\mathrm{SO}_{4-}-$ & $\mathrm{NO}_{3-}$ \\
\hline AM1 & 14.86 & 37.58 & 244.25 & 100.22 & 63 & 366.24 & 29.1 & 518.06 \\
AM2 & 25.25 & 9.98 & 254.88 & 154.28 & 38.1 & 412.08 & 75.8 & 293.49 \\
AM3 & 4.67 & 1.63 & 28.99 & 42.92 & 11 & 34.24 & 0.38 & 93.69 \\
AM4 & 16.3 & 6.4 & 17.24 & 5.61 & 13.1 & 22.51 & 0.31 & 93.39 \\
AM5 & 13.11 & 19.17 & 66.77 & 23.57 & 5.3 & 64.88 & 0 & 296.7 \\
AM6 & 19.28 & 8.11 & 46.26 & 10.63 & 21.1 & 79.46 & 1.24 & 62.05 \\
AM7 & 0.9 & 4.8 & 4.35 & 2.23 & 13.2 & 9.65 & 0.29 & 9.54 \\
AM8 & 4.88 & 2.38 & 7.92 & 2.96 & 18.6 & 8.65 & 0 & 25.66 \\
AM9 & 13.98 & 8.97 & 27.32 & 67.82 & 11.8 & 46.63 & 4.7 & 179.76 \\
AM10 & 2.01 & 1.25 & 9.84 & 8.13 & 4.6 & 9.85 & 0 & 28.97 \\
AM11 & 1.18 & 3.09 & 24.18 & 10.14 & 8.2 & 13.8 & 0.13 & 109.88 \\
AM12 & 11.27 & 5.35 & 23.5 & 16.29 & 20.7 & 24.66 & 5.25 & 83.38 \\
AM13 & 0.61 & 0.09 & 1.98 & 2 & 6.4 & 0.72 & 0.4 & 3.36 \\
AM14 & 2.01 & 2.54 & 21.5 & 1.08 & 14.7 & 19.48 & 7.67 & 6.53 \\
SA01 & 1.19 & 0.49 & 2.94 & 3.06 & 4.8 & 1.58 & 0 & 10.64 \\
SA02 & 8.7 & 2.62 & 8.71 & 13.4 & 13.6 & 13.49 & 0.18 & 61.59 \\
SA03 & 1.11 & 0.51 & 6.96 & 2.99 & 9.8 & 4.47 & 0.35 & 15.51 \\
SA04 & 8.98 & 5.89 & 26.32 & 8.19 & 9.5 & 26.7 & 0.9 & 100.2 \\
SA05 & 3.87 & 0.66 & 4.63 & 2.36 & 11.5 & 3.41 & 0 & 17.23 \\
RIVA & 5.9 & 2.06 & 10.26 & 4.76 & 40.2 & 5.16 & 2.78 & 5.58 \\
L1 & 9.41 & 3.81 & 45.09 & 16.76 & 61.5 & 55.94 & 1.54 & 15.58 \\
\hline & & & & & & &
\end{tabular}

Concentration is in $\mathrm{mg} / \mathrm{L}$ 


\section{References}

Aljaradin M, Persson KM (2012) Environmental impact of municipal solid waste landfills in semi-arid climates case study-Jordan. Open Waste Manag J 5:28-39

Andrianiana H (2013) Contribution to the study of water quality in Andralanitra and surrounding [Contribution à l'étude de la qualité des eaux de consommation d'Andralanitra et environs]. Dissertation. Report for Master's degree, Department of Physics, Faculty of Science, University of Antananarivo

Castañeda SS, Sucgang RJ, Almoneda RV, Mendoza NDS, David CPC (2012) Environmental isotopes and major ions for tracing leachate contamination from a municipal landfill in Metro Manila, Philippines. J Environ Radioact 110:30-37

Davies J (2008) Report on the hydrogeological mapping of North Central Madagascar using Limited Data. In: British geological survey, united states geological survey and cabinet GLW conseil, 2008. République de Madagascar, Hydrogeology, Chap 14. Ministère de L'Energie et des mines (MEM/SG/DG/UCP/PGRM), Projet de gouvernance des ressources minérales (PGRM)

Douessin R (1976) Geography of Antananarivo plain [Géographie des plaines de Tananarive]. Dissertation. University of Antananarivo

Dussarrat B (1992) Interfluve and Peatland hydraulics: an example in weathered basement area (Madagascar) [Hydraulique des unités d'interfluves et des bas-fonds tourbeux: un exemple en zone de socle altéré (Madagascar)]. Thesis dissertation University of Montpellier France 171 pages and appendix

Dussarrat B, Ralaimarp J (1993) Hydrogeological characterization of drainage basins in weathered basement of a high- altitude tropical zone: Hautes terres, Madagascar. Hydrogéologie 1:53-64

Fareze LP, Rajaobelison J, Ramaroson V, Vallet-Coulomb C (2016) Origin and recharge estimation using chemistry and environmental isotopes in the Mahafaly Sedimentary Aquifer, District of Betioky Southwestern Madagascar. Int Res J Earth Sci 4(12):19-27

Farid I, Zouari K, Rigane A, Beji R (2015) Origin of the groundwater salinity and geochemical processes in detrital and carbonate aquifers: case of Chougafiya basin (Central Tunisia). J Hydrol 530(2015):508-532

Fekri A, El Mansouri B, El Hammoumi O, Marrakchi C (2012) Impact of Casablanca municipal landfill on groundwater resources. Int Water Technol J 3:210-216

French Development Agency (2010) Agence francaise de développement. Note de communication publique d'opération. Programme de sécurisation de la décharge d'Andralanitra (Public operation communication note. Andralanitra landfill site securityprogram)

Garman W (1952) Permeability of various grades of sand and peat and mixture of these with soil and vermiculite. USGA J Turf Manag $5: 27-28$

Grillot JC, Ferry L (1990) Surface-underground exchange approach in weathered basement aquifer [Approche des échanges surfacesouterrain en milieu cristallin altéré aquifère]. Hydrol Continent $5(1): 3-12$

Hicks TW, Wilmot RD, Bennett DG (2000) Tritium in Scottish landfill sites. Galson Sciences ltd. (UK), 014-2. Technical document prepared by Galson Sciences Ltd for the Scottish Environment Protection Agency under the terms of the Framework Agreement 230/3010. Oakham, Rutland (UK)

Holland HD, Karl KT (2010) Isotope geochemistry: a derivative of the treatise on geochemistry. Academic Press, London

IAEA (2007) Atlas of isotope hydrology Africa. ISBN 978-92-0-107-207-8

IAEA, Gröning M, Taylor CB, Winkler G, Auer R, Tatzber H (2001) Sixth IAEA intercomparison of low-level tritium measurement in water IAEA report. IAEA, Vienna
IAEA/WMO (2017) Global network of isotopes in precipitationwater resources programme- water isotope system for data analysis, visualization and electronic retrieval. https://nucleus.iaea.org/ wiser. Accessed 13 Feb 2018

Le Sourd J (1999) Dangerous waste management and search of controlled waste implementation site in Antananarivo Madagascar [Gestion des déchets dangereux et recherche des sites pour l'implantation de décharges contrôlées à Antananarivo Madagascar. Travail pratique de diplôme d'ingénieur de génie rural]. Practical work for rural engineering degree. Dissertation

Mann WB, Unterweger MP, Coursey BM (1982) Comments on the NBS tritiated-water standards and their use. Int J Appl Radiat Isot 32(5):383-386

Mazor E (2004) Chemical and isotopic groundwater hydrology, 3rd edn. Marcel Dekker, Inc, New York. ISBN 0-8247-4704-6

Murphy N, Kelleher K, Motherway K, Currivan L (2016) The use of tritium as an environmental tracer of leachate from a landfill site in Ireland. Radiat Environ Med 5(2):44-49

Mutch RD, Mahony JD (2008) A study of tritium in municipal solid waste leachate and gas. Fusion Sci Technol 54(1):305-310

Nigro A, Sappa G, Barbieri M (2017) Application of boron and tritium isotopes for tracing landfill contamination in groundwater. J Geochem Explor 172:101-108

Pogodaiklimat (2016) Antananarivo climate normals 1981-2010 (Temperatures, Precipitation, Humidity). http://www.pogodaiklimat.ru/ climate2/67083.htm. Retrieved 4 May 2016

Raco B, Dotsika E, Battaglini R, Bulleri E, Doveri M, Papakostantinou K (2013) A quick and reliable method to detect and quantify contamination from MSW landfills: a case study. Water Air Soil Pollut 224:1380

Rakoto H, Rajaomahefasoa R, Rasolomanana EH (2017) Optimization of hydrogeological recognition by $2 \mathrm{D}$ geophysical modeling, case of the Ankaraobato-Dorodosy intermediate zone [Optimisation de la reconnaissance hydrogéologique par modélisation géophysique 2D, cas de la zone intermédiaire Ankaraobato-Dorodosy], vol. 1. Madamines, ISSN 2220-0681

Rakotomalala CU (2014) Impact of waste deposit site of Andralanitra on ground and surface water characteristics by isotope techniques [Etude d'impact du dépôt d'ordures d'Andralanitra sur les caractéstiques des eaux souterraines et eaux de surface par les methods isotopiques]. Dissertation. Report for Master's degree, Department of Physics, Faculty of Science, University of Antananarivo

Rasoanaivo Rova (2016) Creation of a Landfill Site and Domestic Waste Treatment Infrastructure in the Municipality of Antananarivo. [Création d'un site de décharge et des infrastructures de traitement de déchets ménagers, dans la commune d'Antananarivo]. Rapport de projet individuel. Département Aménagement et Environnement, Polytech Tours Université François Rabelais-France

Rasolomanana E, Rasolondrazao L, Randrianja R, Robison L, Ralaimaro J, Rakoto H (2011) Water resources problem a s result of industrial and domestic waste in the city of Antananarivo and surrounding [Problèmes de pollution des ressources en eaux posés par les déchets industriels et ménagers dans la ville d'Antananarivo et de ses environs], vol. 2. Madamines, ISSN 2220-0681

Raunet M (1980) Les bas-fonds et les plaines alluviales des hautes terres de Madagascar. Reconnaissance morpho pédologique et hydrologique. Aptitude à la culture de blé de contre saison. (Lowlands and alluvial plains of Madagascar Highlands. Pedologic and hydrologic recognition). Institut de recherches agronomiques tropicales et des cultures vivrières, Pédologie. Ministère du développement rural et de la réforme agraire de la République de Madagascar. 163 Pages and Appendix 
Tazioli A (2011) Landfill investigation using tritium and isotopes as pollution tracers. Acquae Mundi -Am03030: 083-092

Varlam C, Stefanescou I, Varlam M, Faurescou I, Popescou I, Dobrinescu D (2005) Traceability of tritium concentration measurements performed by liquid scintillation method. IAEA/INISINIS, vol 36, Issue 47, Reference Number 36108522
Publisher's Note Springer Nature remains neutral with regard to jurisdictional claims in published maps and institutional affiliations. 